\title{
HODNOTOTVORNÉ PROCESY V ODVETVÍ KULTÚRY
}

\section{VALUE GENERATING PROCESSES IN THE CULTURAL SECTOR}

DOC. ING. MÁRIA FÁZIKOVÁ, CSc.

\author{
ING. MARTin MARIǴ PHD. \\ ING. ōUBICA MAJSTRÍKOVÁ
}

\begin{abstract}
Katedra regionalistiky a rozvoja vidieka $\mid$ Department of Regional and Rural Development Fakulta európskych ğúdií a regionálneho rozvoja Fac. of European Studies and Regional Development Slovenská poQ̆ohospodárska univerzita v Nitre Slovak University of Agriculture in Nitra

$\bowtie$ Trieda Andreja Hlinku 2, 94976 Nitra, Slovak Republic

E-mail:maria.fazikova@uniag.sk,martin.maris@uniag.sk,l.majstrikova@gmail.com
\end{abstract}

\begin{abstract}
Anotácia
Príspevok sa zaoberá analýzou odvetví kultúrneho sektora s úzkym prepojením na odvetvia kreatívneho sektora. Oba sektory spolupôsobia pri vytváraní hodnôt v rámci kreatívnej ekonomiky. Na príklade dvoch prípadových ġúdii: 1)Divadlo Andreja Bagara v Nitre a 2)M ART PRINT, Veđ̆é Záluğie) poukazujeme na hodnototvorný reŠazec pri vytváraní ğpecifického produktu so svojou pridanou hodnotou pre trh. V prípadovej ġúdii 1) sa na tvorbe výsledného produktu ï divadelné predstavenie, nepodieăijú len priami aktéri, ale aj akcesorické podporné ! innosti. V prípadovej ġúdii 2) sú výsledným produktom umelca Ing. Ġறánka, tla! grafických listov, vydavateăká |̣innosડ̌ a organizovanie vernisáǵ v galérii. Hodnototvorný reŠazec v oboch prípadových ġúdiách poukazuje na relativne veăáe mnoğ́tvo ḷánkov na inputovej a outputovej strane, ktoré sú zapojené do hodnotvorného procesu.
\end{abstract}

\section{Klúlové slová}

kultúrny sektor, kreatívna ekonomika, hodnototvorný reŠizec

\section{Annotation}

The paper deals with the analysis of the cultural sector with close links to the creative sector. Both sectors work together to create value within the creative economy. The example of two case studies: 1) Andrej Bagar Theatre in Nitra and 2) ART PRINT VeC̆é Záluğe, points out the value creation chain in creating a specific product with its added value to the market. In case study 1) the formation of the final product - a theatrical performance, not involved only direct actors but also ancillary support activities. In case study 2) are the end product of an artist Ing. Ġpánek, print of engravings, publishing and organizing the opening of the gallery. The value chain creation in both case studies points to a relatively large number of articles on input and output side involved in value chain process.

Key words

cultural sector, creative economy, value chain creation

\section{JEL classification: Z11}

\section{Uvod}

Odvetvia kultúrneho a kreatívneho sektoru predstavujú dve úzko spojené nádoby, ktorých spolol ným výstupom je ǵpecifický produkt s vlastnou pridanou hodnotou pre trh. Ak uvaǵujeme globálne, ako hnací motor znalostnej ekonomiky, kreatívny a kultúrny sektor zohráva ! oraz viac kđ̣̆! ovú úlohu pri 
priŠahovaní talentu a investícii, tvorbe medzinárodnej reputácie a katalýze inoval ných aktivít v rámci iných sektorov ekonomiky. Kreatívna ekonomika je !̣asto charakterizovaná ako výsledok produktu zaloǵeného na synergii Q̊dskej tvorivosti, mobility, technologickej vyspelosti a záujmu | loveka o humanizáciu spolo!̣ nosti. V N̦alǵom výskume sa treba zameraŠ nielen na niekođ̆o väl ğch kozmopolitných centier, ktoré sú | asto vnímané ako kđ̛̣| ové, kreatívne, ekonomické hnacie sily a na druhej strane veQ̆ malých, periférnych miest, ktoré sú vnímané ako ekonomický neúspech. Takýto pohăd vğkk len prehlbuje priestorovú nerovnováhu, ktorá v konel nom dôsledku neprispieva k udróateĞ́ému rastu. Kreativitu moǵno nájš̌ vo vğtkých odvetviach a miestach, vrátane periférie. (Milotová, Chreneková; 2012)

\section{CieOa Metódy}

Cie@̆m príspevku je posúdiŠ a zhodnotiŠ komplexicitu hodnototvorných procesov na príklade dvoch prípadových ġúdii z odvetvia kultúrneho prostredia. Procesy na inputovej a outputovej strane predstavujú systém odberateQ̆ko-dodávateQ̆kých väzieb medzi jednotlivými |lánkami hodnototvorného reŠazca. Výsledky obsiahnuté v oboch ǵúdiách pochádzajú z primárneho výskumu uskutol neného na základe interview s pomocou dotazníka s vedúcimi predstaviteŎni oboch respondovaných inġitúcii. V prvej prípadovej guúdie ig̉o o riaditeă DAB Nitra ï Ján Greg்g a v druhej prípadovej ǵúdii, majiteă galérie a tlạ iarne M ART PRINT ï Ing. Martina Ġ円ánka. Výsledky interview sa pougóli pri zostavovaní hodnototvorného reŠazca a analýze dodávateQ̆koodberateQ̆kých väzieb, trhu a zákazníkov.

\section{Výsledky}

\section{Hodnototvorný reŠazec kultúrneho odvetvia}

Hodnototvorný reŠazec zobrazuje !̣innosti v rámci firmy, ktoré navrhujú, vyrábajú, predávajú, dodávajú a podporujú firemný produkt. Porter (1985) charakterizuje hodnototvorný reŠazec ako spojenie hodnotvorných !̣ inností a marğe. Hodnototvorné !̣innosti sú fyzicky a technologicky odlig̉né ! innosti, ktoré firma vykonáva a prerozdeQ̆jje ich na primárne a podporné ! innosti. Primárne ! innosti sú !̣innosti zahrnuté do fyzickej tvorby produktu, jeho predaja a distribúcii zákazníkovi, a na ich podporu slúǵia podporné !̣innosti. Marğa predstavuje rozdiel medzi celkovou hodnotou a celkovými nákladmi na vykonanie vğtkých potrebných li inností.

Hodnototvorný reŠazec kultúry, ako odvetvia, má niekoăo charakteristických Ị̆:

- tvorba hodnoty a jej validácia na nehmotné aktíva má cyklický charakter (dôleğitosŠ spätnej väzby),

- kultúrny cyklus identifikujeme na 5 stupŔov:

1. Tvorba: vznik a autorizácia myğienky a obsahu. Na tomto stupni vzniká Ăsurovinañ pre kultúrny priemysel.

2. Produkcia: spojenie vğetkých elementov (zásobovanie, zariadenia, profesionáli), ktoré sú potrebné pre realizáciu kultúrnej myğienky a jej obsahu.

3. Rozg̈rovanie diela (disseminácia): prináğanie produktov kultúry spotrebiteØ̆m.

4. Predvádzanie/prijímanie: predstavuje miesto spotreby a jeho prínos pre spotrebite@̆v. Prijímanie znamená transfer vedomostí a zrul ností, ktoré neobsahujú ğiadne obchodné transakcie, ale ktoré sa vyskytujú iba $\mathrm{v}$ procese prenosu nehmotného kultúrneho dedil stva $\mathrm{z}$ generácie na generáciu.

5. Spotreba/úl asড̌ znamená aktivity spotrebiteŎv a úl astníkov spotrebujúcich produkty kultúry pri zúl ast'́ovaní sa na kultúrnych aktivitách (napr. ! ítanie kníh, návğeva divadelných predstavení, návġeva galérií, poḷ úvanie rádia).

- stupne kultúrneho cyklu sú cyklicky prepojené, ḷiǵe vzŠahy majú sieŠový charakter (umoǵŔuje vznik nových foriem produkcie, zvy! ajne na základe novej technológie)

- kultúrny cyklus má priestorové aspekty (aktivity sa môǵu koncentrovaŠ na jednom mieste, v regióne alebo v krajine, iné sú rozğrené celosvetovo) 
- medzi zloǵkami reŠazca (subjekty tvoriace kreatívny obsah, distribuḷ né kanály, koneḷ ní spotrebitelia, vzdelávacie inġitúcie, inġitúcie verejnej správy, dodávatelia) identifikujeme komplexné väzby a interakcie, ktoré spravidla pôsobia v oboch smeroch

- subjekty tvoriace kreatívny obsah sú charakteristické diverzifikovanou ! innosŠou

- výrazná interakcia medzi tvorcami kreatívneho obsahu a vzdelávacími inġitúciami (| astokrát ide o symbiotický vzŠah)

- kanálmi distribúcie sú napríklad galérie, divadlá, vydavateQ̆tvá, centrá voĞého l! asu

- inġitúcie verejnej správy sú integrované vo väl ğej miere, ! o pramení z faktu, ǵe produkty kultúry sú povaǵované za Asemi-verejnéñ statky

- silný sociálny kapitál

\section{Prípadová g̛údia ï hodnototvorný reŠazec ĂDivadlo Andreja Bagara (DAB)ñ}

Divadlo Andreja Bagara v Nitre (DAB) je najvýznamnejğm aktérom odvetvia kultúry v Nitrianskom samosprávnom kraji a uznávanou konġantou v stavbe slovenského profesionálneho divadla. Svoje meno nesie po významnom slovenskom hercovi, reǵisérovi, pedagógovi a organizátorovi divadelného ǵivota - Andrejovi Bagarovi. Dramaturgia DAB vychádza v ústrety domácemu aj zahranil nému publiku a zohădŔuje jeho rôznorodosડ Tematická a ǵánrová pestrosડ̌ sa prelína s vysokou nárol nosŠou i atraktívnosŠou javiskového diela. V konkrétnych inscenáciách sa odzrkadQ̆je originalita reğijných osobností, ich výrazný rukopis, estetický ǵýl, poetika a svojská interpretácia diel. V repertoári nechýbajú základné piliere svetovej klasiky a modernej drámy 20 . storoḷ ia. Divadlo sa pravidelne venuje uvádzaniu diel pre deti a mladého diváka. Za prirodzenú povinnosŠ povaǵuje uvádzanie diel slovenských autorov, súl asníkov aj klasikov.

Na tvorbe výsledného produktu ï divadelného predstavenia ï sa podieQ̆jú priami aktéri, ktorými sú dramaturgia divadla, jeho vedenie a umelecký kolektív. Nemenej dôleǵté, v prípade takého veăeého divadla, ako je DAB, sú podporné !̣ innosti zabezpel ované internou infrağruktúrou divadla a externí dodávatelia.

\section{Externí dodávatelia}

Na zal iatku hodnotového reŠazca ï na vstupoch do hodnototvorného procesu stoja dve hlavné skupiny dodávateŎv. Sú to dodávatelia materiálnych vstupov, ako sú energie, sluớby, materiály potrebné na tvorbu scény, kostýmov, dodávatelia ozvul ovacích a osvetQ̄vacích technológií. ńalej sú to sluğby, ako napr. tla! informal ných a propagal ných materiálov. Títo sú lokalizovaní v priestore celého Slovenska, ale aj v zahraniḷí. V hodnotovom reŠazci sa nedá presne rozlíǵšs̆ do ktorej ! asti hodnototvorného postupu externé dodávatelia hmotných vstupov a sluğieb vstupujú. Napr. dodávatelia materiálov na tvorbu scény a kostýmov vstupujú do hodnotového reŠazca na jeho zaḷiatku, dodávatelia energií sa nachádzajú vo vg̉etkých jeho segmentoch, a napr. tla! iarenské sluớby vstupujú do reŠazca v jeho distribu! nej ! asti. Druhú skupinu tvoria dodávatelia nemateriálnych vstupov ako sú autori divadelných predlôh, reğiséri, scénografi, orchestre, nahrávacie gúudiá, kostýmoví výtvarníci, externí herci. Títo sú, vzhădom na jazykovú obmedzenosŠ predovğetkým z priestoru Slovenska. Dodávatelia nemateriálnych vstupov sa taktieǵ nachádzajú vo vg̉etkých sekvenciách reŠazca. Napr. externí reǵiséri, nahrávacie gúúdia, orchestre, výtvarníci, pôsobia najmä v sekvencii produkcie, externí herci, tanel níci alebo hudobníci pôsobia vo vğetkých jeho sekvenciách, aj keN̦ váha ich práce spoḷ íva najmä v sekvencii prezentácie.

\section{Interná infrag்ruktúra}

Distribúcia $\mathrm{v}$ hodnotovom reŠazci predstavuje marketing divadla, ktorého výsledkom je predaj vstupeniek na predstavenie. V tejto l, asti reŠazca je divadlo veŎni úspeğé. Obsadenosડ jeho predstavení je 90\%, ! o je vysoko nad slovenský priemer. Zásluhu na tom má samotná dramaturgia divadla, spôsob nağudovania, aj kvalita umeleckého súboru. $Z$ manaǵérskej stránky je vğgik zodpovedné za marketing obchodné oddelenie divadla, ktoré pre predaj vstupeniek vyuğiva najmä priamy marketing. Komunikuje najmä s firmami, ġkolami a inými inġitúciami, ktoré sú jeho dlhodobými zákazníkmi. Prostredníctvom takýchto dlhodobých vzŠahov distribuuje väḷginu vstupeniek na predstavenia. Okrem toho sa snaǵi rozg̈rovaŠ portfólio divákov prostredníctvom reklamy v médiách, ako aj prostredníctvo rôznych PR aktivít. Divadlo teda realizuje najmä stratégiu 
vyuǵitia trhu, t.j. usiluje sa upevniŠsi postavenie na danom trhu, ale aj stratégiu rozğrenia trhu, keN̦ sa usiluje získaŠ nové trhy pre svoje produkty v iných regiónoch aj v iných gátoch. Pre umelcov je dôleğité budovaŠsi vzŠahy so sprostredkovateŎni umenia (umelecké ġkoly, médiá, premiéry, kritici) a s publikom. Tieto mu pomáhajú zhodnocovaŠ nehmotné aktíva. Významnou súl asŠou hodnotového reŚazca v scénickom umení je propagácia a vzŠahy s verejnosŠou a s médiami. Túto !innosŠ zabezpel uje propaga! né oddelenie DAB. Propagáciu zabezpel uje DAB niekoQ̆x́mi kanálmi. Je to predovğetkým prostredníctvom zájazdov na iných divadelných scénach. ńalej je to prostredníctvom úl asti na divadelných festivaloch. Divadlo vyvíja aj iné PR aktivity ako napr. Reprezenta! ný ples v divadle, módna prehliadka dvoch svetov: divadla a módy, autogramiáda hercov DAB, deŔotvorených dverí, deŔ detí. Divadlo si buduje svoju znal ku aj inými aktivitami, ako napr. ĂVianol ný balí| ek z DABñ ï dar! ekové balenie vstupeniek na muzikál Tisícroḷ ná v!̣ ela s medom, ozdobnou sviel kou a medovinou. Divadlo poskytuje svoje priestory pre rôzne výstavy. VeQ̆ á sála je ! asto prenajímaná na prezentáciu predstavení iných divadiel. $\mathrm{V}$ rámci $\mathrm{PR}$ divadlo spolupracuje s nákupno-zábavnými centrami , $\mathrm{s}$ rádiami a televíziami a printovými médiami. Divadlo spolupracuje s obcou kritikov, ktorí sa zúl astnili na vǵetkých premiérach. Významnou súl asŠou PR DAB je priamy marketing zacielený na konkrétne inğitúcie, ktoré sú pravidelne oslovované s ponukami na návg̉evu divadelných predstavení. Táto forma marketingu prináğa divadlu nemalý finan!̣ý efekt, ale aj nových návġevníkov. Divadlo sa propaguje prostredníctvom internetovej stránky www.dab.sk ako aj na sociálnej sieti Facebook.

Ekonomické sluğby zabezpel ujú ekonomický a právny servis, sú zodpovedné za správne nakladanie s finan!̣ nými prostriedkami ako aj za personálnu prácu.

Umelecko-technická podpora je zabezpel ovaná umelecko-technickou prevádzkou. Jej úlohou je zabezpel ovaŠ stavby scénických dekorácií na vg̉etky predstavenia doma i na zájazdoch, profesionálne osvetlenie a ozvul enie veQ̆kej sály a ostatných hracích priestorov vybavených modernou divadelnou technikou. O odborné lí! enie, maskovanie a parochne sa starajú kvalifikovaní vlásenkári a maskéri, o prípravu a údróbu kostýmov a rekvizít garderobierky a rekvizitári. Sluǵby pre verejnosŠ: moǵnosŠ zapoğil ania niektorých komponentov divadelnej techniky s odbornou obsluhou. Umelecko-dekora! ná podpora je poskytovaná umelecko-dekoral nými dielŔami. Vg̉etky divadelné dekorácie na predstavenia DAB podQ̆ návrhov scénických výtvarníkov vyrábajú pracovníci stolárskej, zámol níckej, ! láúnnickej a maliarskej dielne. Divadelné kostýmy na vysokej profesionálnej úrovni pripravuje pánska a dámska kraj! írska dielŔa.

\section{Obr. 1: Hodnototvorný reŠazec Divadla Andreja Bagara}

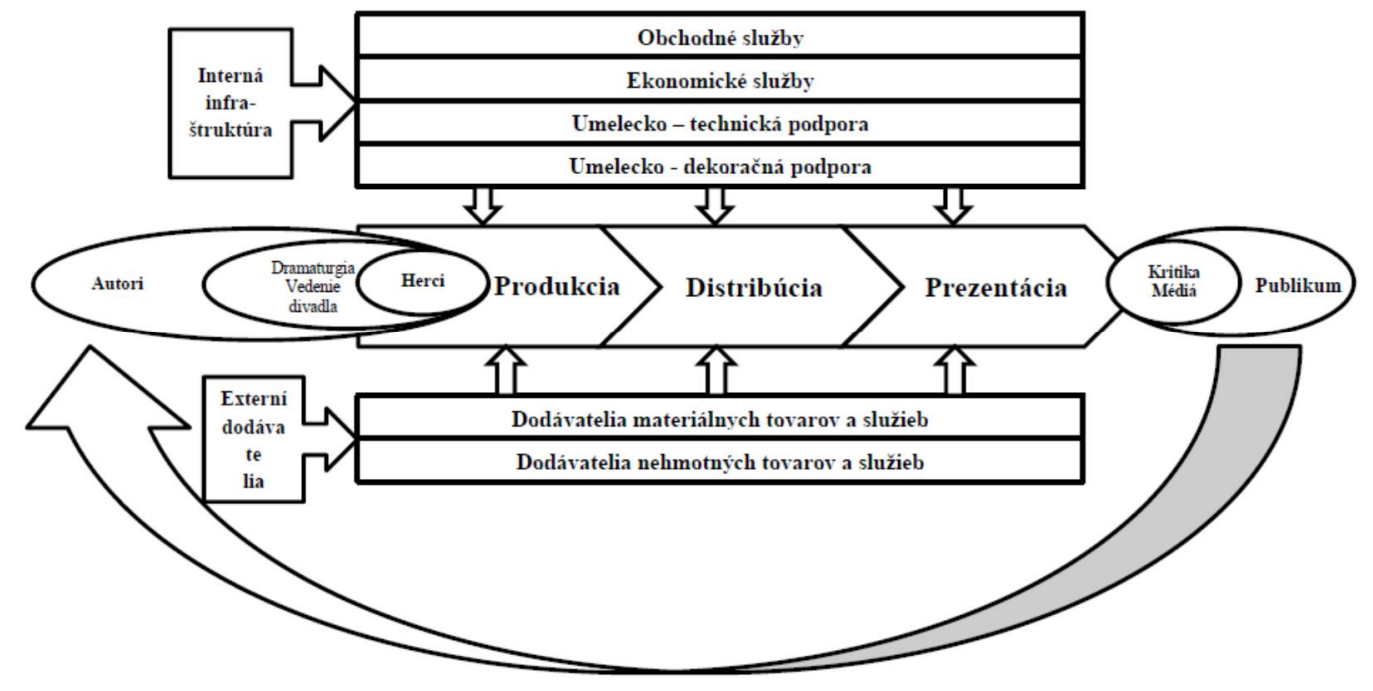

Zdroj: vlastné spracovanie, 2013 


\section{Prípadová g̛údia - hodnototvorný reŠazec Ing. Martin Ġ円ánek M ART PRINT}

Ing. Ġepánek pôsobí v obci Veăé Zálugóie (okres Nitra), kde sa v rámci svojej hlavnej pracovnej náplne venuje tlạ i grafických listov a ako vedQ̆jg̉e l, innosti môǵeme zadefinovaŠ rámovanie obrazov, vydavateQ̆kú !̣innosŠ (bibliofilská edícia) a prevádzkovanie galérie (v rámci ktorej organizuje vernisáǵe). Galéria bola zaloǵená v polovici roku 2008. Príl inami boli najmä zmena trvalého bydliska do VeQ̆eého Záluğa, kde pri rodinnom dome bola veQ̆á hospodárska budova (pre pôvodné !̣innosti stal ila len malá výmera budovy), ktorá mala veQ̆ký nevyugoitý priestor a aj potreba prezentovaŠ diela umelcov, organizovaŠ ich stretnutia a workshopy. Taktieǵ bola vízia pozdvihnutia kultúrneho povedomia obḷ anov vo Veăxom Záluǵí, avğak tento cieÔnebol naplnený.

Zo schémy hodnototvorného reŠazca vyplýva pomerne ğroko diverzifikované portfólio produktovej !̣innosti zakladajúcej sa na tlạ i grafických listov a rozvíjajúca sa o rámovanie, prevádzkovanie galérie a vydavateQ̆kú ! innos Š ZadávateŎni pre tieto ! innosti sú umelci, ktorí si objednávajú tla! grafických listov, rámovanie, ale aj moǵnosŠ vystavovašs svoje diela. Takisto aj fyzické osoby majú moǵnosŠsi daŠzarámovaŠsvoje umelecké diela.

Hlavnými dodávateŎni pre tla! sú dve zahranil né firmy z Holandska a Rakúska, ktoré môǵeme oznal iŠ za exkluzívne, z hădiska ich ponúkaného tovaru, keṆǵe dodávajú g̣peciálny papier a farby. Na Slovensku neexistujú firmy, ktoré by disponovali vhodným tovarom pre túto l innosŠ, keṆǵe dopyt po týchto produktoch je minimálny. Hlavným dodávate@̆m pre rámovanie je firma z TopoØ̣̆ian, ktorá dodáva nielen rámy, ale aj rôzne iné materiály a nástroje potrebné na linnosŠ ńalğm dodávate@̆m je firma zo G̣iaru nad Hronom, ktorá poskytuje spojovací materiál, avğkk jej sluǵby Ing. Ġß̣ánek vyuğiva pribliǵne raz za dva roky, pretoǵe v rámci jednej dodávky si objedná tovar na dlhý ḷasový horizont. V oblasti prevádzkovania galérie sa vystavujú rôzne umelecké diela, nielen od grafikov, ale aj od rôznych sochárov a maliarov. Kaǵdá otváracia vernisáǵ je spojená s kultúrnym programom a obl erstvením. Toto ob! erstvenie je zabezpel ené pomocou cateringovej firmy. Na vytvorení vhodného kultúrneho programu sa podieăjú umelecké ġkoly z Nitry, ale aj herci a speváci, ktorí sú poväl ġne v priateQ̆kom vzŠahu s vystavujúcim umelcom alebo prevádzkovateQ̆m galérie. Pre vydavateQ̆kú ! innosŠ nie sú potrební iní dodávatelia, keṆǵe sa vyuğiva rovnaký materiál ako na tla! grafických listov.

OdberateŎni grafických listov sú umelci, ktorí aj zadávajú poǵiadavku na tla!̣. Tento istý proces sa opakuje aj v prípade rámovania, keṆǵe umelci, resp. fyzické osoby, ktoré si dajú zarámovaŠ svoje umelecké diela, si ich následne aj vyzdvihnú. Poḷ as vernisáǵi si záujemcovia môǵ́ vystavované diela zakúpiŠ Kupujúcimi sú najmä zberatelia umenia, ale aj fyzické osoby, ktoré hădajú dekorácie do svojich priestorov. Vo vydavateQ̆kej !̣innosti sa Ing. Ġß̧ánek sústreṆuje najmä na tla! kalendárov, ktoré obsahujú grafiky od rôznych známych umelcov. KeṆǵe hodnota jedného výtlal ku je vysoká, zákazníkmi sú solventné firmy, ktoré produkt vyuğivajú na reklamné úl ely.

\section{Obr. 2: Hodnototvorný reŠazec - Ing. Martin Ġ̉ánek M ART PRINT}

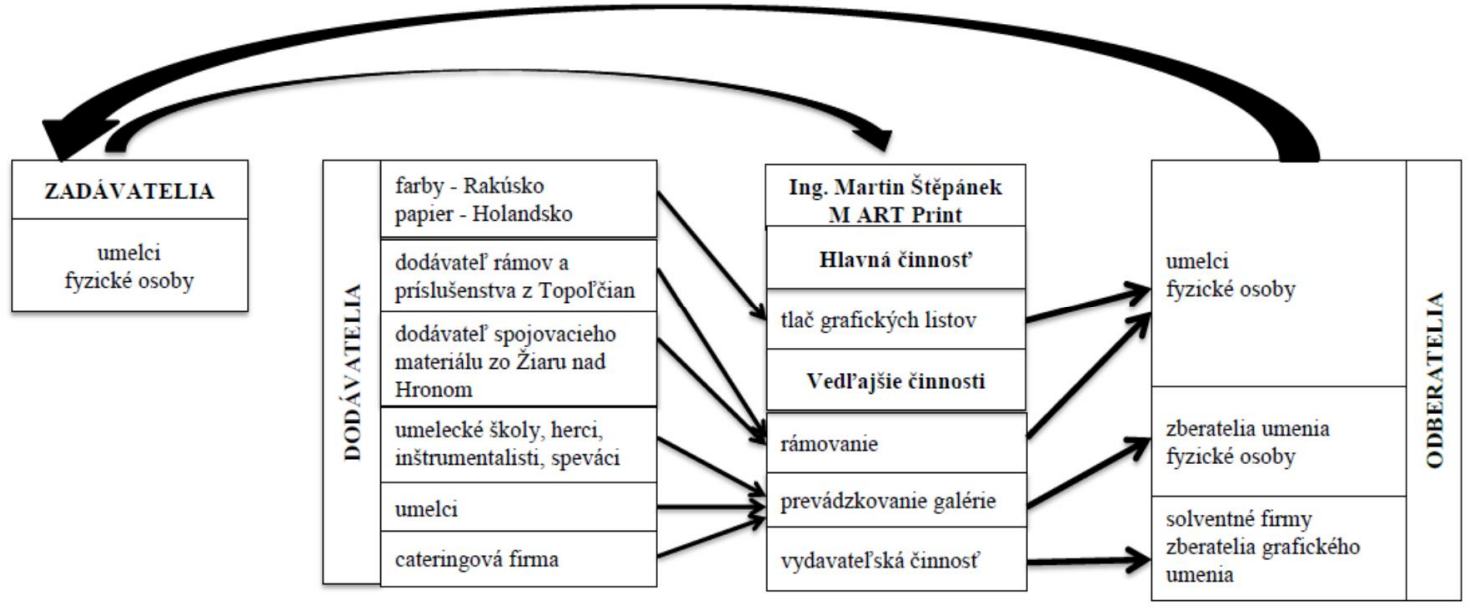

Zdroj: vlastné spracovanie, 2013 


\section{Záver}

V oboch sledovaných prípadoch môǵeme pozorovaŠ cyklickosŠ reŠazca, !̣iǵe vstup a výstup sú prepojené cez spätnú väzbu. U Ing. Ġ円̧ánka sú !̣ asto krát umelci a fyzické osoby zadávateŏni objednávky a zároveŔaj ich odberateŏni. V prípade divadla publikum poskytuje spätnú väzbu nielen hercom po predstavení, ale aj dramaturgom, vedeniu divadla a autorom predstavenia. Odliğhosti medzi DAB a !̣innosŠou Ing. Ġగpánka sú najmä vo veăkosti podniku, jeho ğruktúre a v trhu. DAB má zloǵitú ğruktúru, l o je viditeăé aj v hodnototvornom reSazci, zatiaỌ o Ing. Ġepánek má jednoduchú organizal nú ğruktúru, keṆǵe v podniku pracuje spolu so svojim synom a pracovníl kou na dohodu. Trh pre divadlo je lokalizovaný pre región, keṆǵe aj väl g̉na dodávateŎm pochádza z Nitrianskeho samosprávneho kraja. Takisto aj zákazníci, ! iǵe diváci sú väl ğnou z regiónu, ! o je dané jazykovou bariérou a nutnosŠou cestovaŠ do divadla. Dochádza k skupinovej spotrebe. Na druhej strane Ing.

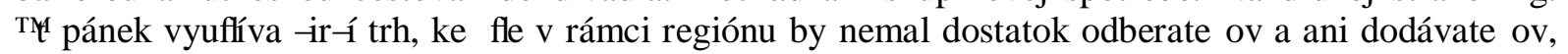
a tak cestuje za svojimi zákazníkmi aj mimo regiónu, ! ím dochádza k individuálnej spotrebe.

\section{Literatúra}

[1] FÁZIKOVÁ, M., CHRENEKOVÁ, M., MELICHOVÁ, K. Divadlo Andreja Bagara (DAB). [výzkumná studie v rámci grantu APVV 0101-10].

[2] MARIĠ M., MAJSTRÍKOVÁ, ō. M. Art print. [výzkumná studie v rámci grantu APVV 0101-10].

[3] MILOTOVÁ, B., CHRENEKOVÁ, M., (2012). Kreativita na vidieku. In IX. national and regional economics. Kog̈ce : Technical University, pp. 309-317. ISBN 978-80-553-1215-6.

[4] MILOTOVÁ, B., CHRENEKOVÁ, M., (2013). Creative industries in Nitra region .In Regional economics in new perspectives. Winter seminar of regional science. Bratislava: Ekonóm. ISBN 978-80-225-3607-3.

[5] PORTER, E.M., (1985). Competitive Advantage. New York: Free Press. ISBN 978-4165-9584-7.

Príspevok bol spracovaný v rámci grantu APVV 0101-10 Kreatívna ekonomika ï národohospodárske a regionálne podmienky a stimuly. 